\title{
Cutting duration and performance parameters of a harvester's sawing unit under real working conditions
}

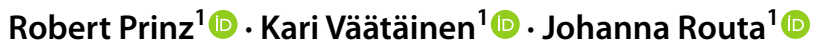

Received: 31 March 2020 / Revised: 22 July 2020 / Accepted: 15 September 2020 / Published online: 30 September 2020

(c) The Author(s) 2020

\begin{abstract}
Amongst all the working elements of single grip harvesters, the working elements of felling and processing play an important role within the cut-to-length (CTL) harvester's working phases. This includes the felling cutting and cross-cutting of stems within the felling and processing operation. The detailed investigation of such individual machine activities may help to analyse and improve the performance of forest machines. The objective of this study was to investigate the cutting duration and other performance parameters, including the fuel consumption, of a CTL harvester's sawing unit under real working conditions. Detailed information on the felling cutting and cross-cutting performance was collected at short intervals using CAN bus data of two single grip harvesters in final felling from two different sites in Eastern Finland. As a result, models for effective time consumption in the work phase of cutting as a function of stem size were developed, both for felling cutting and cross-cutting. Felling cutting and cross-cutting durations were somewhat identical until the cutting diameters of 400-450 mm, depending on the site. Thereafter, the cutting time difference increased and was higher in felling cutting. At the site with large diameters of $550-650 \mathrm{~mm}$, the difference varied between $15 \%$ and $28 \%$, between the comparisons of formulae. In addition, other performance parameters, including the respective fuel consumption of this working phase, were part of the study. The study revealed a higher hourly based fuel consumption for the entire guide bar movement time compared to the pure cutting time in cross-cutting with stem diameters below $400 \mathrm{~mm}$. Detailed knowledge of the performance of the sawing unit's activities might help the planning process of future studies, as well as support the future development of efficient and intelligent machinery.
\end{abstract}

Keywords Mechanised harvesting $\cdot$ Felling cutting $\cdot$ Cross-cutting $\cdot$ Fuel consumption $\cdot$ CTL harvesting

\section{Introduction}

Improving the cost-effectiveness of forest operations and reducing the fuel consumption of the work are currently amongst the main targets in the field of forest technology. Furthermore, a focus on energy efficiency to improve profitability has been recognised by wood procurement enterprises (Haavikko et al. 2019). Until the early 2000s, the main focus of forest operations was on the improvement of mechanical performance. The value and production of high-value products have since been in more focus (Brown

Communicated by Eric R. Labelle.

Robert Prinz

robert.prinz@luke.fi

1 Natural Resources Institute Finland (Luke), P.O. Box 68, 80100 Joensuu, Finland et al. 2020). Purpose-built cut-to-length (CTL) harvesters have developed over the years and have high productivity, utilisation, and fuel efficiency compared to excavator-based machines in comparable operations (Magagnotti et al. 2017). Various approaches have been taken to improve the performance of individual machines (e.g. Prinz et al. 2018), as well as the entire operational system involving other machines, e.g. forwarders for off-road transport (e.g. Laitila et al. 2007; Manner et al. 2013) or machines responsible for relocation to new sites (Väätäinen et al. 2006).

Amongst all the working elements of single grip harvesters, the working elements of felling the tree and processing the stem (i.e. delimbing and cross-cutting) play an important role within the CTL harvester's working phases. This is especially the case when the quality of cutting is also considered to avoid cutting damage (see Inberg et al. 2002) and when additional cuts are also needed. It is also the case 
when processing rotten parts of the stem (see Kärhä et al. 2019). The aim of both is to produce high-quality products.

Several studies have assessed the performance (e.g. cutting efficiency) and duration of felling, and cross-cutting in motor-manual operations using chainsaws (e.g. Câmpu and Ciubotaru 2017; Marenče et al. 2017; Ciubotaru and Câmpu 2018). However, only a limited number of studies are available on mechanised harvesting using CTL harvesters. Nurminen et al. (2006) studied the time consumption for different CTL harvester working elements and showed the average work phase times as a proportion of the total effective time, with felling contributing to $17 \%$ and processing $45 \%$ of the total in final felling $18 \%$ and $27 \%$ in thinning. Kärhä et al. (2019) mentioned an average share of $61 \%$ of processing time (incl. delimbing, cross-cutting, sounding) of total stem processing time in Norway spruce stems. In a study with an excavator-based harvester, Labelle et al. (2017) presented an average percentage distribution of productive work cycle elements, with felling contributing to $9.6 \%$ and processing to $51.2 \%$ of the total in spruce thinning when applying automated bucking, $10.2 \%$ for felling, and 59.1\% for processing for pine. This includes the felling cutting and cross-cutting of stems within the felling and processing operation. Väätäinen et al. (2005) mentioned the share of cross-cutting time within a processing time of $15 \%$ in final felling and $20 \%$ in first thinning at an average stem volume of 0.53 and $0.13 \mathrm{~m}^{3}$. A study by Alam et al. (2014) resulted in an average cross-cutting time of 1.82 and $1.64 \mathrm{~s}$, with two different Valmet 475EX harvesters equipped with a Rosin 997 harvester head on larger stems, with processed tree volumes of 1.8 (diameter at breast height over bark $39 \mathrm{~cm}$ ) and $2.4 \mathrm{~m}^{3}$ (diameter at breast height over bark $51.2 \mathrm{~cm}$ ).

The time consumption of felling depends on stem size. Delimbing and cross-cutting also increases as a function of stem size (Väätäinen et al. 2005; Nurminen et al. 2006). The material used also plays a role. Jönsson et al. (2016) showed a variation of approximately $6 \%$ within brand new chains for the cutting time and energy consumption using a test rig.

In addition to the time consumption of work cycle elements, the fuel consumption of machines has been studied under real working conditions. However, the focus was typically not on cutting performance alone. Work studies on the fuel consumption of harvesters have been conducted under different conditions. For example, harvesters and their fuel consumption in main felling operations (Klvac and Skoupy 2009) or thinning (Prinz et al. 2018) have been studied. This has also been studied by applying different methods, e.g. the carbon balance method (Lijewski et al. 2017) or the technique that uses a datalogger connected to the Controller Area Network (CAN bus), a robust vehicle bus standard for the machines (Suvinen and Saarilahti 2006; Prinz et al. 2018; Melander and Ritala 2020). The machines' data can be utilised to analyse or improve the performance of the forest machines, e.g. shown by Nuutinen et al. (2010), who determined the time and energy efficiency of tested feed rollers of a harvester head using CAN bus data. The machines' fieldbus time series data can also be combined with open forest data to further examine the relationship between the performance of forest machines and forest attributes, as proposed by Melander et al. (2019). As stated, automatic data recording allows the cost-effective collection of detailed information under real working conditions with short recording intervals. Thus, with the help of high-frequency machine data, a detailed investigation of an individual machine activity, such as felling cutting or cross-cutting, may help to analyse and improve the performance of forest machines.

The aim of this study was to investigate the cutting duration and other performance parameters of a CTL harvester's sawing unit under real working conditions using CAN bus data. An objective was to develop models for effective time consumption in the work phase of cutting as a function of stem size, both felling cutting and cross-cutting, as well as to study the respective fuel consumption of this working phase.

\section{Material and methods}

\section{Experimental design}

The study took place on 14 and 18 March 2019 under real working conditions during winter felling operations in Finland, with temperatures between $-5{ }^{\circ} \mathrm{C}$ and $+3{ }^{\circ} \mathrm{C}$ (Fig. 1). The operations were located in eastern Finland at two different final felling sites: site A, near Onkamo $\left(62^{\circ} 21^{\prime} 48 \mathrm{~N}\right.$, $30^{\circ} 08^{\prime} 11 \mathrm{E}$ in WGS 84 ); and site $\mathrm{B}$, near Tuusniemi $\left(63^{\circ} 22^{\prime} 16 \mathrm{~N}, 28^{\circ} 35^{\prime} 04 \mathrm{E}\right.$ in WGS 84), each with sitespecific stand parameters (Table 1).

\section{Characteristics of the studied harvesters and their sawing units}

The studied machines were two CTL harvesters (Table 2), a Ponsse Scorpion (site A) and a Ponsse Ergo (site B). Both machines were equipped with the same guide bar type and their respective new chains. The standard guide bars and chains suitable for the specific machine and harvester head type were used. In both machines, Ponsse-branded Oregon guide bars with a length of $750 \mathrm{~mm}$, the JET-FIT base type, and sprocket nose with a number of 16-17 teeth and $2 \mathrm{~mm}$ Trilink sawing chains were used. The sawing chains were replaced with new ones at approximately hourly intervals for each machine, or immediately in the case of a blunt chain. One guide bar was used and turned at the same time as the chain was changed (site A), or a new guide bar was mounted with each change of the chain (site B). 


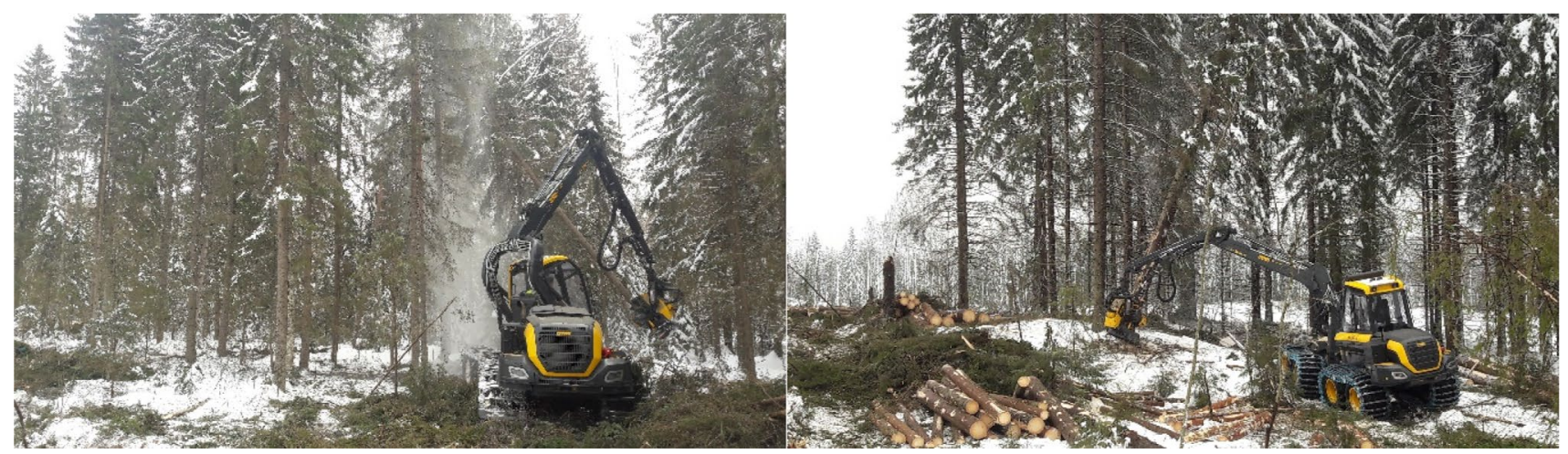

Fig. 1 CTL harvesters under real working conditions at the 2 studied sites, a Ponsse Scorpion (left) and a Ponsse Ergo (right)

Table 1 Summary of key site parameters and processed stems

\begin{tabular}{lrr}
\hline & Site A & Site B \\
\hline Share of species (\%) & & \\
Scots pine (Pinus sylvestris L.) & 24 & 2 \\
Norway spruce (Picea abies [L.] Karst.] & 44 & 86 \\
Silver birch (Betula pendula Roth.) & 32 & 7 \\
Other broadleaves & & 4 \\
Total number of stems & 244 & 205 \\
Number of accepted fellings & 172 & 132 \\
Mean felling cutting diameter (mm) & 252 & 364 \\
Total number of cross-cuttings & 1125 & 1114 \\
Number of accepted cross-cuttings & 928 & 907 \\
Mean cross-cutting diameter (mm) & 163 & 250 \\
\hline
\end{tabular}

Table 2 Summary of key parameters of studied harvesters and their sawing unit at each site

\begin{tabular}{lll}
\hline Site & Site A & Site B \\
\hline Harvester type & Ponsse Scorpion & Ponsse Ergo \\
Model year & 2018 & 2019 \\
Wheels & 8 & 8 \\
Engine power $(\mathrm{kW})$ & 210 & 210 \\
Harvester head & $\mathrm{H} 6$ & $\mathrm{H} 7$ \\
Crane type & $\mathrm{C} 50$ & $\mathrm{C} 44+$ \\
Typical weight $(\mathrm{kg})$ & 21,900 & 21,500 \\
\hline
\end{tabular}

The guide bar pushing pressures were automatically adjusted by the machine according to the stem diameter. The oil pressures for sawing were set by the machines, but typically range between 200 and 240 bar with a maximum of 280 bar. The speed of the saw chains was also set by the machines, but typically ranged between 7500 and $8000 \mathrm{rpm}$. Each machine was operated by an experienced operator with more than 20 years of work experience in mechanised harvesting using the typical operating technique for respective cutting operations.

\section{Study methodology}

The method applied was to describe the relationship between performance and the factors influencing the work. The performance was studied in the form of continuous time studies (Harstela 1991), using the machine data. A datalogger was connected to the CAN and ArcNet buses of the machines and recorded the various relevant machine parameters directly from the machines in intervals of $0.1 \mathrm{~s}$. Recorded parameters included instant fuel consumption, sawing time, and the position of the guide bar in relation to the guide bar pocket at the harvester head. Machine data included the stem diameter at the felling cutting and cross-cutting positions, stem information, tree species, log length, and log volume. The felling cutting diameter was an estimated value. This was because the diameter measurement was conducted with the feed rollers (i.e. using triangle measurement), and the first measurement recording of each stem was located $130 \mathrm{~cm}$ from the point of the felling cutting position. As provided by the law of timber measurement in Finland, a tree speciesspecific formula for the butt end diameter estimation of each stem was used in harvesters' stem measurements (see Lindblad et al. 2018).

Calibration was carried out for the felling cutting diameters with the sample. The sample size of 55 stems ( 29 stems at site A and 26 stems at site B) was measured manually with a calliper at the cutting height, using cross-measurement with an accuracy of $0.1 \mathrm{~cm}$. Thus, correction factors for the felling cutting diameters provided by the machines' forecasts were established in the form of a regression analysis, and the correction models were applied to all felling cutting diameters.

The diameter correction based on manual stem diameter measurements resulted in 2 main linear regression models, one for site A (Eq. 1), and one for site B (Eq. 2). 
Site A:

$y=-22.6+1.08 x_{\mathrm{m}}$

where $y$ is the corrected diameter for felling cutting ( $\mathrm{mm}$ ) and $x_{\mathrm{m}}$ is the felling cutting diameter estimated by machine $(\mathrm{mm})$.

Site B:

$y=-21.0+1.02 x_{\mathrm{m}}$

where $y$ is the corrected diameter for felling cutting ( $\mathrm{mm}$ ) and $x_{\mathrm{m}}$ is the felling cutting diameter estimated by the machine $(\mathrm{mm})$.

Under the given testing conditions, the calibration showed a tendency for the machine to overestimate small felling diameters and underestimate large diameters at site $\mathrm{A}$; at site $\mathrm{B}$, overestimation was about the same at the range of diameters.

The diameter distribution of accepted stems at the felling phase varied within the sites. Site A showed a higher share of diameter at the lower end of the scale; site B showed a higher diameter distribution (Fig. 2).

The higher average diameter of stems at site B compared to site $\mathrm{A}$ is even more obvious with the diameter distribution of accepted cross-cuttings (Fig. 3).

Each recorded movement of the guide bar was included in data analysis, with the following specifications:

- Felling cutting began when the guide bar started to move and ended when the guide bar reached the maximum distance from the starting point, excluding the return movement of the guide bar.

- Cross-cutting began when the guide bar started to move and ended when the guide bar reached the maximum dis- tance from the starting point, excluding the return movement of the guide bar.

In addition to the datalogger, the test periods were digitally recorded by video with a recording density of 25 images per second. A digital video camera was attached either to the screen of the harvester (at site A) or placed on the operator's head (at site B) without disturbing their performance. The video recording was used to visually confirm the correct linkage of machine data with recorded observations, detect and approve the cutting phases, including their accuracy, and erase obvious mistakes and outliers observed. To validate the timing accuracy of CAN bus monitoring for the cutting elements, 10 sample cross-cuts were randomly selected from the video from each site, and time durations of cross-cuttings were checked and compared to analysed data from the CAN bus. At site A, the average difference between video monitoring and CAN bus monitoring was $-0.9 \mathrm{~ms}$, with a standard deviation of $3.3 \mathrm{~ms}$; at site $\mathrm{B}$, the respective values were 2.0 and $4.0 \mathrm{~ms}$. Concerning the validation data, the cutting diameter varied between 68 and $390 \mathrm{~mm}, 102$ and $446 \mathrm{~mm}$, at sites A and B, respectively. The cross-cutting diameter and tree species had no effect on accuracy.

In video checking, outlier erasing was done in cases when the guide bar got stuck under the edge of the tree during felling cutting, was jammed below the log end after crosscutting, or when the operator made an extra bar movement a few centimetres away from the cut edge of a log without sawing the stem before the stem feeding. In addition, some of the guide bar's double movements during cutting were erased (the bar did not visit the bucket between these movements). In some cases, the observation was erased due to the cross-cutting of the stem with double tops, which resulted in both extreme duration and error for the cutting diameter.
Fig. 2 Diameter distribution of accepted stems at felling height at both studied sites

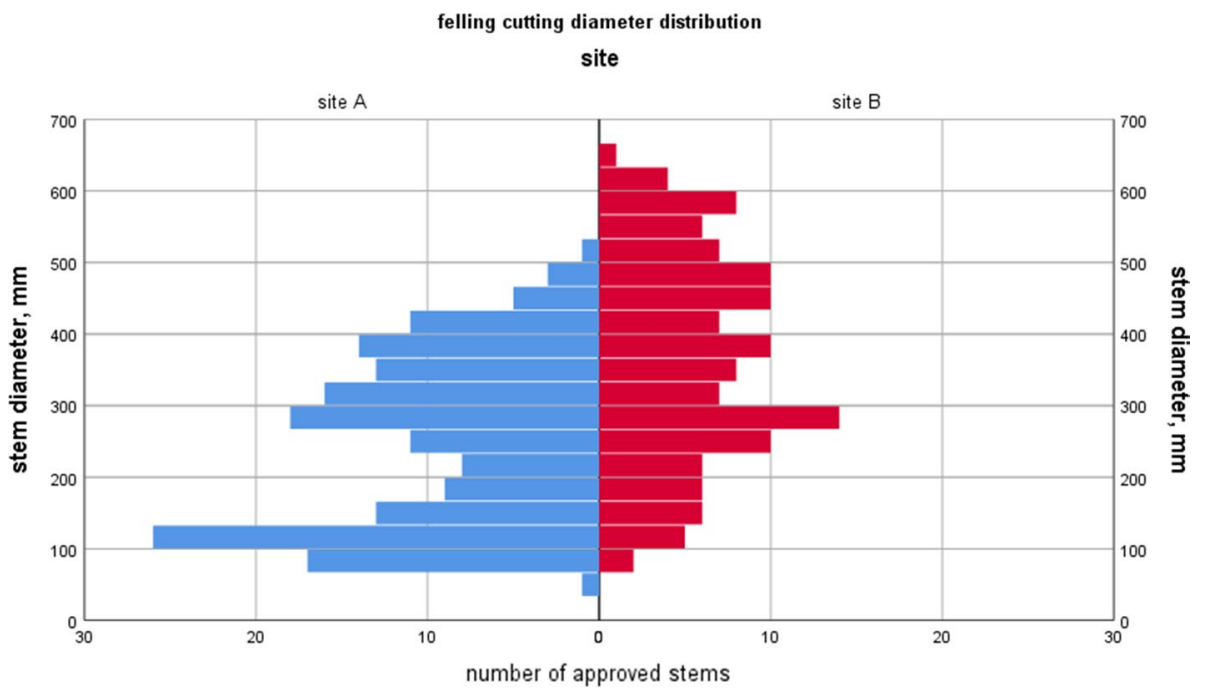




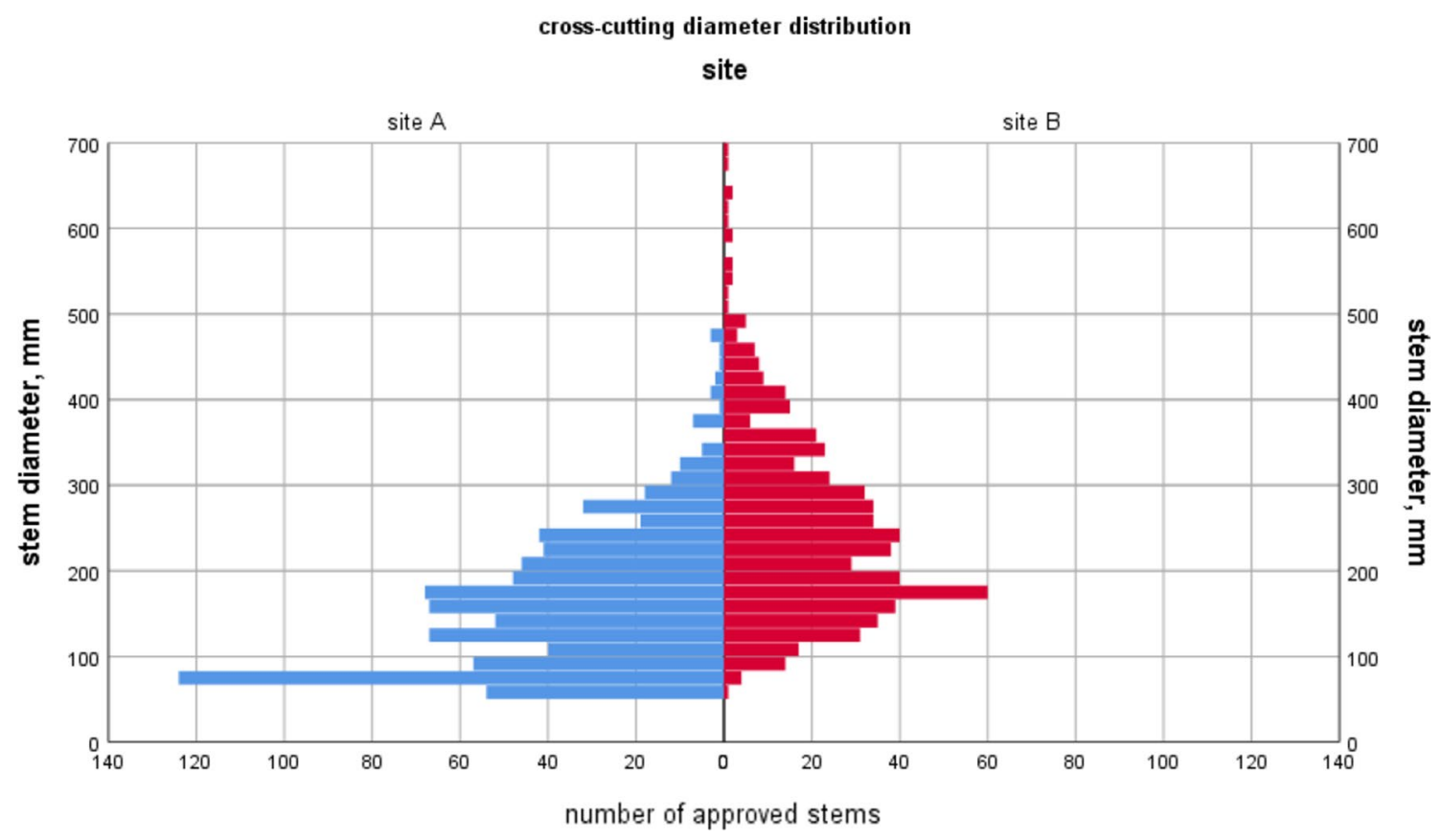

Fig. 3 Cross-cutting diameter distribution of accepted stems at both studied sites

A single cutting observation was accepted for further analysis in cases when:

- The felling cutting was connected to an existing standing tree

- The felling cutting was not followed by an additional cut of the butt end

- The felling cutting was completed in one cut

- The cross-cutting was connected to a valid diameter

- The cross-cutting was connected to a valid cutting value

- The cross-cutting was completed in one cut

\section{Statistical analyses}

Altogether, the research data at site A included an effective working time of $137 \mathrm{~min} 5 \mathrm{~s}$, whilst the research data at site B included an effective working time of $141 \mathrm{~min}$ $14 \mathrm{~s}$. The statistical analyses were performed using SPSS 25 statistical software, and a significance level of $\alpha<0.05$ was applied in all analyses. Non-parametric tests were used because normality and homogeneity assumptions were not met. Data was treated separately for each site and cutting type (felling and cross-cutting). Cutting duration and fuel consumption did not differ statistically between tree species. Thus, all species and observations were treated in the same data. Cutting duration and respective fuel consumption were included in the analyses in cases where the cutting duration was $\geq 10 \mathrm{~ms}$ to erase obvious outliers. Other data points were not removed after the initial screening using the video material. $N$ equals the number of accepted stems during cutting. A regression analysis was performed with the cutting duration as the dependent variable, and the stem diameter as the independent variable; similarly, regression models were made with the absolute fuel consumption per cut and the hourly fuel consumption as the dependent variable, and the stem diameter as the independent variable.

\section{Results}

\section{Cutting duration}

A non-parametric test (Independent Samples Mann-Whitney $U$ test) rejected the null hypothesis that the cutting duration was the same for sites and cutting types (felling cutting or cross-cutting) in addition to the differences between the machines used, including their specific parameters and the site conditions (i.e. diameter and species distribution). Data was therefore presented separately for each site and cutting type (felling cutting and cross-cutting).

\section{Felling cutting duration}

Regression models estimating felling cutting time were formed for each site with individual coefficients (Eq. 3). The time consumption for felling cutting increased as a 
function of the stem diameter. At both sites, the regression showed a good fit for an exponential relationship under the given stem diameters (Fig. 4). The statistical characteristics of regression analysis-based models are shown in Table 3.

$t_{\text {fell }}=a \mathrm{e}^{(b x)}$

where $t_{\text {fell }}$ is the time consumption for felling cutting (ms) and $\mathrm{x}$ is the stem diameter (mm) and $a, b$ are the site-specific coefficients:

Site A: $a=24.92225698213123, b=0.003945770137317886$;

Site B: $a=17.81253636943527, b=0.004418670638191134$.

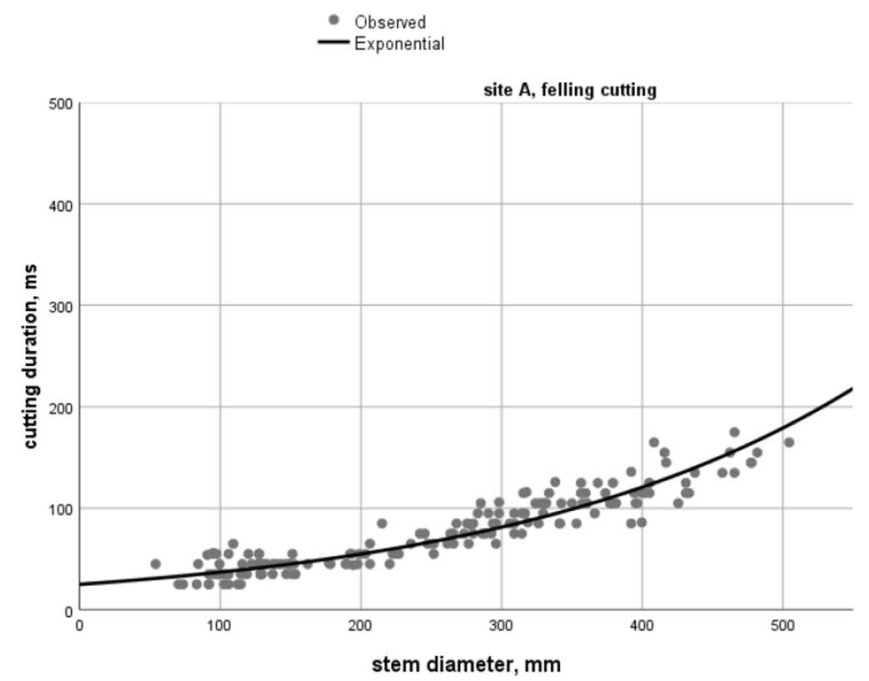

\section{Cross-cutting duration}

Regression models estimating the cross-cutting time were formed for each site with individual formulae (Eq. 4). The time consumption for cross-cutting increased as a function of the stem diameter. At both sites, the regression showed the best fit for a cubic relationship under the given stem diameters (Fig. 5). The statistical characteristics of regression analysis-based models are shown in Table 3.

$t_{\text {cross }}=a+b x+c x^{2}+\mathrm{d} x^{3}$

where $t_{\text {cross }}$ is the time consumption for cross-cutting (ms) and $x$ is the stem diameter $(\mathrm{mm})$ and $a, b, c, d$ are the sitespecific coefficients:

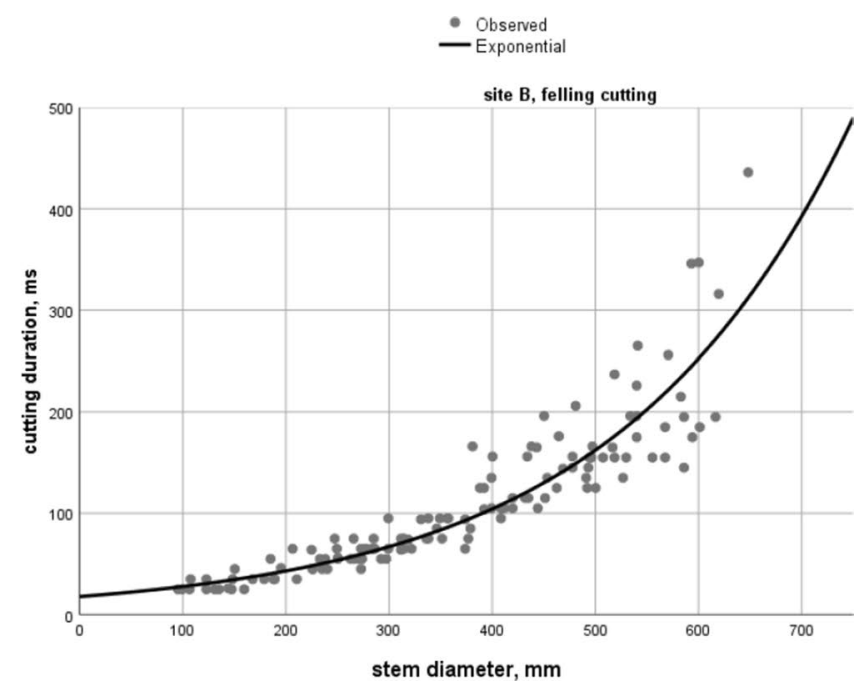

Fig. 4 Felling cutting duration as a function of stem diameter at both studied sites (left: site A; right: site B)

Table 3 Statistical characteristics of regression analysis-based models ( $t=$ time consumption for cutting phase, ms, $x=$ stem diameter, $\mathrm{mm}$ )

\begin{tabular}{|c|c|c|c|c|c|c|c|c|c|c|}
\hline \multirow[t]{2}{*}{ Cutting phase model } & \multirow{2}{*}{$\begin{array}{l}\text { Dependent } \\
\text { variable }\end{array}$} & \multirow[t]{2}{*}{$R^{2}$} & \multirow{2}{*}{$\begin{array}{l}F \text {-test } \\
F \text {-value }\end{array}$} & \multirow[t]{2}{*}{$p$} & \multirow[t]{2}{*}{$N$} & \multirow[t]{2}{*}{ Term } & \multicolumn{2}{|c|}{ Constant/coefficient } & \multicolumn{2}{|l|}{$t$-test } \\
\hline & & & & & & & Estimate & Std Error & $t$-value & $p$ \\
\hline \multirow[t]{2}{*}{ Felling cutting, site A (Eq. 3) } & \multirow[t]{2}{*}{$t_{\text {fell }}$} & \multirow[t]{2}{*}{0.865} & \multirow[t]{2}{*}{$1,047.137$} & \multirow[t]{2}{*}{$<0.001$} & \multirow[t]{2}{*}{165} & Constant & 24.922 & 0.847 & 29.440 & $<0.001$ \\
\hline & & & & & & $x$ & 0.004 & 0.000 & 32.359 & $<0.001$ \\
\hline \multirow[t]{2}{*}{ Felling cutting, site B (Eq. 3) } & \multirow[t]{2}{*}{$t_{\text {fell }}$} & \multirow[t]{2}{*}{0.909} & \multirow[t]{2}{*}{$1,241.662$} & \multirow[t]{2}{*}{$<0.001$} & \multirow[t]{2}{*}{126} & Constant & 17.813 & 0.874 & 20.381 & $<0.001$ \\
\hline & & & & & & $x$ & 0.004 & 0.000 & 35.237 & $<0.001$ \\
\hline \multirow[t]{4}{*}{ Cross-cutting, site A (Eq. 4) } & \multirow[t]{4}{*}{$t_{\text {cross }}$} & \multirow[t]{4}{*}{0.879} & \multirow[t]{4}{*}{$1,980.297$} & \multirow[t]{4}{*}{$<0.001$} & \multirow[t]{4}{*}{819} & Constant & 16.408 & 2.064 & 7.951 & $<0.001$ \\
\hline & & & & & & $x$ & 0.199 & 0.035 & 5.638 & $<0.001$ \\
\hline & & & & & & $x^{2}$ & -5.046 & 0.000 & -0.029 & 0.977 \\
\hline & & & & & & $x^{3}$ & 3.224 & 0.000 & 1.304 & 0.193 \\
\hline \multirow[t]{4}{*}{ Cross-cutting, site B (Eq. 4) } & \multirow[t]{4}{*}{$t_{\text {cross }}$} & \multirow[t]{4}{*}{0.934} & \multirow[t]{4}{*}{$2,860.012$} & \multirow[t]{4}{*}{$<0.001$} & \multirow[t]{4}{*}{612} & Constant & 32.603 & 3.736 & 8.727 & $<0.001$ \\
\hline & & & & & & $x$ & -0.138 & 0.040 & -3.433 & 0.001 \\
\hline & & & & & & $x^{2}$ & 0.001 & 0.000 & 7.324 & $<0.001$ \\
\hline & & & & & & $x^{3}$ & -4.196 & 0.000 & -3.386 & 0.001 \\
\hline
\end{tabular}



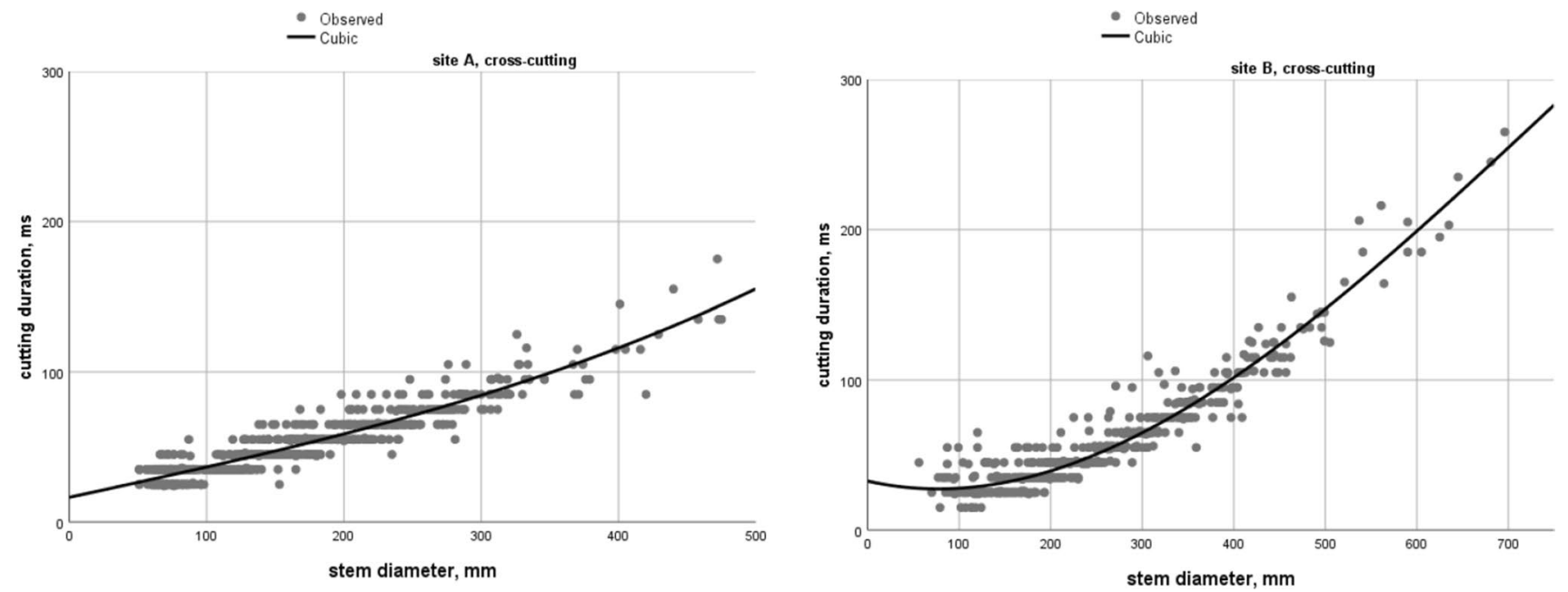

Fig. 5 Cross-cutting duration as a function of stem diameter at both studied sites (left: site A; right: site B)

Site A : $a=16.4083287422018$, $b=0.1994237803888788, c=-5.045850188646531 \mathrm{e}^{-006}$, $d=3.223744302964626 \mathrm{e}^{-007}$;

Site B: $a=32.60268029583651$, $b=-0.1379377446596923, c=0.0009438663011260352$, $d=-4.196352613620209 \mathrm{e}^{-007}$.

Felling cutting and cross-cutting durations were somewhat identical until the cutting diameters of $400-450 \mathrm{~mm}$, depending on the site. Thereafter, the cutting time difference increased and was higher in felling cutting. At site B, with the large diameters of 550-650 mm, the difference varied between $15 \%$ and $28 \%$, between the comparisons of formulae.

\section{Performance parameters}

In addition to the cutting duration, the study included additional performance parameters of the harvester's sawing unit, such as fuel consumption, and the difference of the cutting duration compared to the duration of the entire guide bar movement and the respective fuel consumption.

\section{Fuel consumption}

This section presents results on fuel consumption, studied as instant fuel consumption recorded by the machines during the cutting phases. The hourly fuel consumption in litres per hour $\left(\mathrm{h}^{-1}\right)$ during the felling cutting at site A showed a mean value of $22.92 \mathrm{lh}^{-1}$ (std error $0.23 ; N=172$ ) and a mean of $27.4 \mathrm{lh}^{-1}$ (std error $\left.0.49 ; N=132\right)$ at site $\mathrm{B}$.

During cross-cutting, the hourly fuel consumption at site A showed a mean value of $17.08 \mathrm{lh}^{-1}$ (std error 0.13 ; $N=928)$ and a mean of $22.45 \mathrm{lh}^{-1}$ (std error $\left.0.21 ; N=907\right)$ at site B.
The absolute fuel consumption during the cutting was presented as a function of the stem diameter. At both sites and in both cutting processes (felling cutting and cross-cutting), the regression showed a good fit for a cubic relationship under the given stem diameters (Eq. 5). The $R^{2}$ values indicated that between $86 \%$ and $92 \%$ of the cases could be explained by the respective functions (Fig. 6).

$f=a+b x+c x^{2}+\mathrm{d} x^{3}$

where $f$ is the fuel consumption during cutting (ml) and $x$ is the stem diameter ( $\mathrm{mm}$ ) and $a, b, c, d$ are the site- and cutting-type-specific coefficients.

The absolute fuel consumption during both cutting phases showed somewhat adjacent values until cutting diameters of approximately $400 \mathrm{~mm}$ (Fig. 6). For higher stem diameters, the cutting time difference increased and was higher in felling cutting. At site $\mathrm{B}$, with a large diameter of $550 \mathrm{~mm}$, a difference of $29 \%$ occurred between the comparisons of the formulae for felling cutting and cross-cutting.

\section{Effect of guide bar movement time compared to cutting duration}

This section presents results on the difference of the cutting duration compared to the duration of the entire guide bar movement and the respective absolute fuel consumption. Although the cutting duration previously described consisted of the time when the saw was actually cutting the stem, the entire movement of the guide bar included the return movement of the guide bar in addition to the cutting duration. Thus, the guide bar movement covered the entire movement of the guide bar, from leaving the starting position until the return to a stable position. 

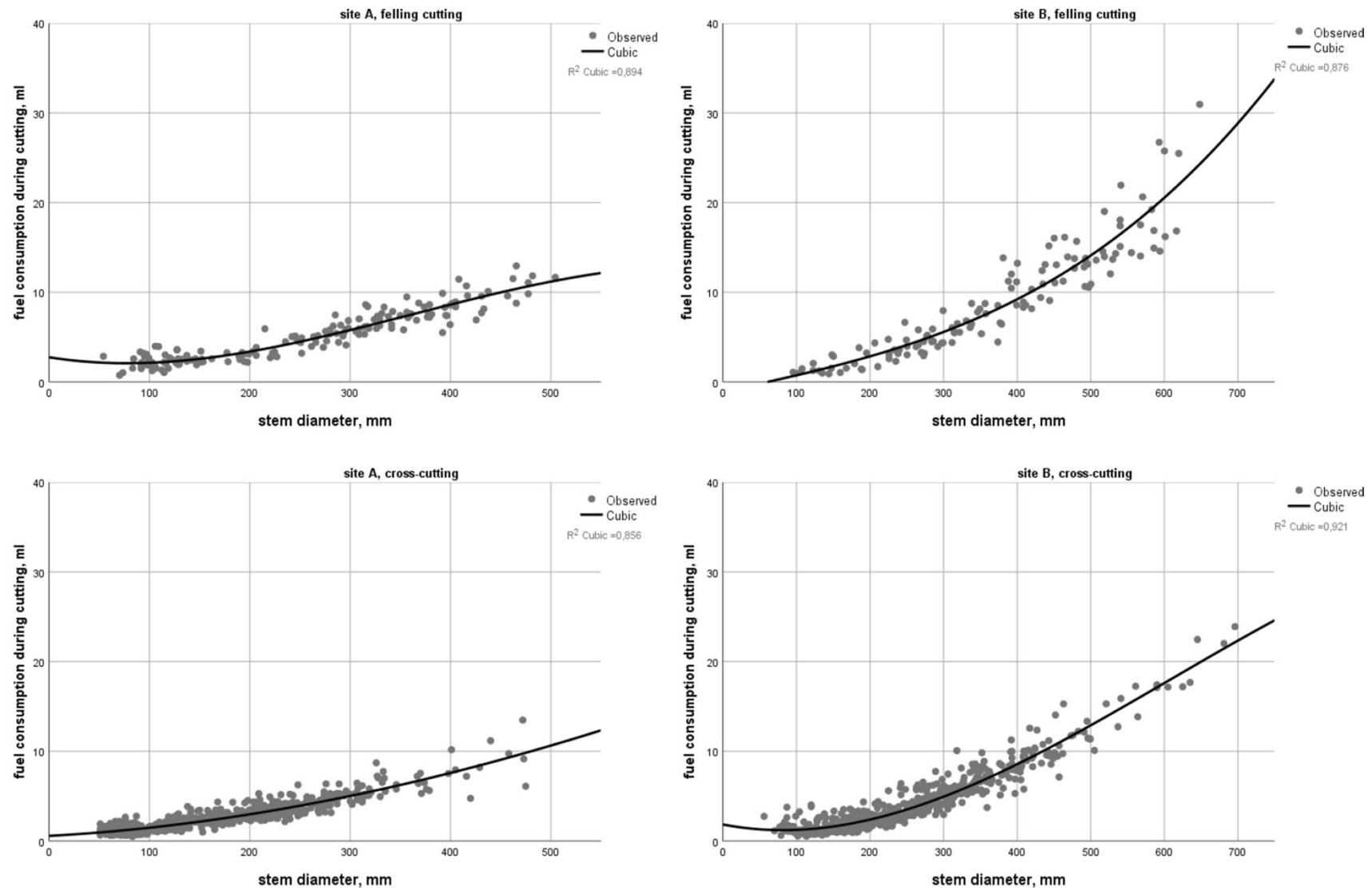

Fig. 6 Absolute fuel consumption during cutting (felling cutting and cross-cutting) as a function of stem diameter at both studied sites (upper left: site A, felling cutting; upper right: site B, felling cutting; lower left: site A, cross-cutting; lower right: site B, cross-cutting)

The total duration for the entire guide bar movement (cutting duration and return movement of guide bar) during the felling cutting at site A showed a mean value of $110.96 \mathrm{~ms}$ (std error $5.58 ; N=166$ ) and a mean of $206.22 \mathrm{~ms}$ (std error $15.52 ; N=127)$ at site $\mathrm{B}$. The mean values of the pure felling cutting duration represent $68.5 \%$ of the entire guide bar movement for site A and $53.3 \%$ for site B.

During cross-cutting, the total duration for the entire guide bar movement at site A showed a mean value of $69.43 \mathrm{~ms}$ (std error $0.93 ; N=820$ ) and a mean of $86.04 \mathrm{~ms}$ (std error $2.47 ; N=613$ ) at site $\mathrm{B}$. The mean values of the pure cross-cutting duration represented $78.6 \%$ of the entire guide bar movement for site A and $70.4 \%$ for site B.

The absolute fuel consumption for the entire guide bar movement (cutting duration and return movement of guide bar) during the felling cutting at site A showed a mean value of $7.31 \mathrm{ml}$ (std error $0.41 ; N=166$ ) and a mean of $15.39 \mathrm{ml}$ ( $\operatorname{std}$ error $1.06 ; N=127)$ at site $\mathrm{B}$. The mean values of the absolute fuel consumption during the pure felling cutting duration represented $69.1 \%$ of the mean values for the entire guide bar movement for site A and $58.1 \%$ for site B. During cross-cutting, the absolute fuel consumption for the entire guide bar movement at site A showed a mean value of
$3.84 \mathrm{ml}$ (std error $0.07 ; N=820$ ) and a mean of $6.56 \mathrm{ml}$ (std error $0.21 ; N=613$ ) at site B. The mean values of the absolute fuel consumption during the pure cross-cutting duration represented $72.9 \%$ of the mean values for the entire guide bar movement for site A and $65.5 \%$ for site B.

The hourly fuel consumption for pure sawing time versus the entire guide bar movement during cross-cutting as a function of stem diameter at both studied sites followed a cubic relationship similar to the absolute fuel consumption per cut (see Eq. 5). The regression models showed a good fit for cross-cutting for pure cross-cutting $\left(R^{2}=61.8\right.$; $F$-value: $439.396 ; p:<0.001 ; N=819)$ and for the entire guide bar movement at site $\mathrm{A}\left(R^{2}=70.9 ; F\right.$-value: 661.557 ; $p:<0.001 ; N=819)$, as well as for site B for pure cross-cutting $\left(R^{2}=62.9 ; F\right.$-value: $\left.344.246 ; p:<0.001 ; N=612\right)$ and for the entire guide bar movement at the same site $\left(R^{2}=58.8\right.$; $F$-value: $289.986 ; p:<0.001 ; N=612)$. Figure 7 shows the regression curves for the hourly fuel consumption, comparing the pure cutting with the entire guide bar movement during cross-cutting as a function of stem diameter at both studied sites.

Of the pure cutting time at both sites, the average fuel consumption increased until about $500 \mathrm{~mm}$ of cutting 


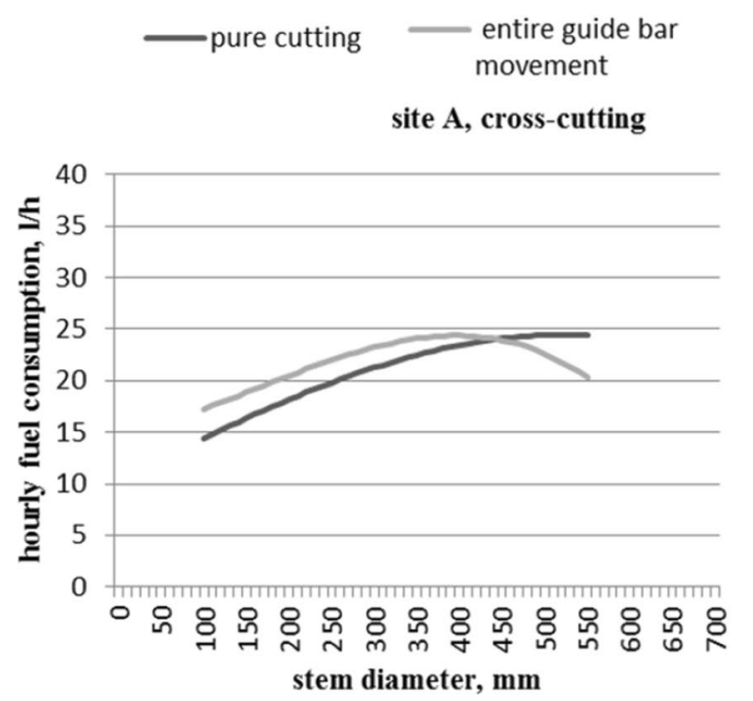

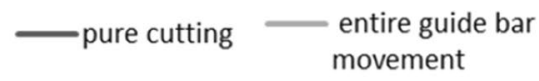

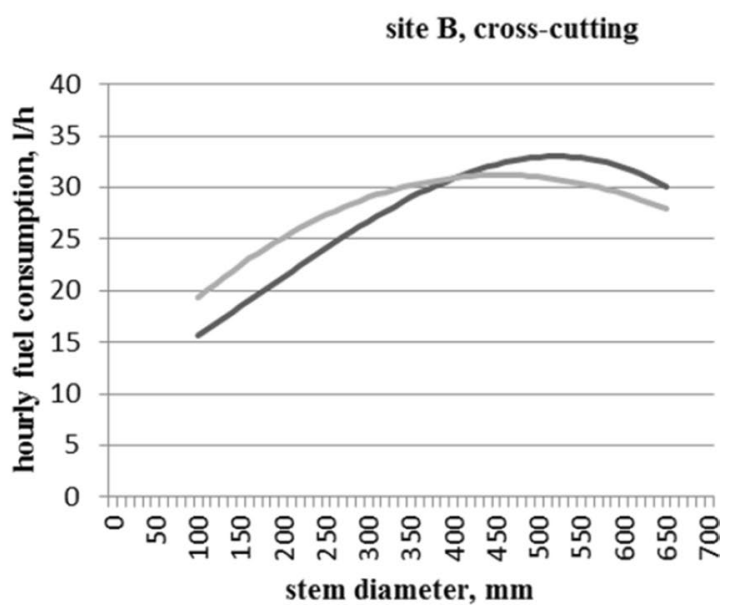

Fig. 7 Comparison of functions for the hourly fuel consumption during both pure sawing and the entire guide bar movement during cross-cutting as a function of stem diameter at both studied sites (left: site A; right: site B)

diameter, after which a decline occurred. The same tendency, although a little earlier, could be seen in the entire guide bar movement, with peak fuel consumption at roughly $400 \mathrm{~mm}$. The fuel consumption curves also reveal that the cross-cutting process (pure cutting) for stem diameters of $500 \mathrm{~mm}$ consumed $69 \%$ more fuel per hour compared to stem diameters of $100 \mathrm{~mm}$ at site A, and even $110 \%$ at site B. For the entire guide bar movement, fuel consumption curves show that for stem diameters of $500 \mathrm{~mm}$ the hourly fuel consumption was $31 \%$ higher compared to stem diameters of $100 \mathrm{~mm}$ at site A and $61 \%$ at site B.

\section{Discussion}

The calibration of the felling cutting estimation by the harvester head was necessary to correct the estimation error and thereby improve the precision of the performance data. Estimation errors within the range of felling diameters resembled the findings of Lindblad et al. (2018), especially at site A. The applied calibration of stem diameters was therefore conducted under the given testing conditions to correct the machines' forecast stem diameter at the felling cutting position, due to the tendency to overestimate small diameter stems and underestimate larger stem diameters. Lu et al. (2017) also underlined the possible need to correct the machine measurements of harvested stems extracted from the harvester data to estimate tree heights. Performed diameter sensing by Möller et al. (2008) showed that an average of $68 \%$ of recorded values was within $4 \mathrm{~mm}$ of the manually cross-callipered measurements. However, no tested system achieved an operational accuracy of 90\% (Möller et al. 2008). Although the manual measurements of 55 stumps in this study are a fairly limited amount, the dimensions of forecasting errors behaved similarly to those described by Lindblad et al. (2018).

The study's findings on the cross-cutting duration are approximately in line with the cutting duration presented by Alam et al. (2014) at the second site when comparing similar diameters of approximately $500 \mathrm{~mm}$. For smaller stem diameters, the study revealed lower cross-cutting durations, in contrast with the results of Alam et al. (2014). The difference between felling cutting and cross-cutting durations with large diameters might be explained by the influence of tree weight during felling and the log's moment of force during cross-cutting. Although all the tree species were retained in the same analyses because there was no statistical difference between species, it might be expected that in larger tree diameters the cutting of silver birch might consume more time because of the higher density of wood compared to spruce and pine.

The identification of the cutting time duration and fuel consumption during this phase was based on the harvester machines' automatic data collection. Although previous studies showed that time studies based on manually detected data compared to automatic data collection showed only minor differences (Arlinger and Möller 2014), the fuel consumption presented in this study was considered a relative estimate because of the lack of direct measurements or real consumption values. Nevertheless, the results might indicate the fuel consumption for the particular cutting activity as part of the entire operation, and it allowed a relatively precise comparison of the proportional change in fuel efficiency, whilst the cutting diameters varied.

The results showed low absolute fuel consumption values due to the respective durations of cutting activity. 
Previous studies focused on the presentation of fuel consumption figures for the entire operation, based on case studies or larger follow-ups. A reported total average calculated diesel consumption of 1,1671 per $1,000 \mathrm{~m}^{3} \mathrm{ub}$ for single-grip harvesters was based on a Swedish questionnaire study (Athanassiadis 1999). Holzleitner et al. (2011) conducted a long-term machine data follow-up in Austria and presented the fuel consumption of harvesters between 10.2 and $24.31 \mathrm{PMH}_{15}{ }^{-1}$, and an average of $15.61 \mathrm{PMH}_{15}{ }^{-1}$ and 0.0951 per hour and kilowatt of engine power. Magagnotti et al. (2017) showed a median fuel consumption of 9.81 $\mathrm{PMH}^{-1}$ or $0.71 \mathrm{~m}^{-3}$, based on annual records for purposebuilt harvesters in Italy. Based on a recent long-term follow-up study in Finland, Kärhä et al. (2020) reported an hourly fuel consumption of $16.0 \mathrm{lh}^{-1}$ for harvesting operations in final felling. Considering the calculated hourly fuel consumption for the cutting activity presented in this study, these values are very high, nearly double, and depending on the study, even nearly three times the overall average consumption presented by the mentioned literature. This indicates the higher power requirement during cutting operations at that time for such an activity. The results also showed that the absolute fuel consumption for the entire guide bar movement was higher compared with the pure cutting activity for both cutting types and at both sites. In return, the mean duration of the pure cutting activity represented the main share of the time consumption, with values between $53 \%$ and $79 \%$ for the entire guide bar movement duration.

The consumption of oil used to lubricate the saw chains to reduce friction was not part of this study; Athanassiadis (1999) suggested 351 of harvester's saw chain lubrication oil for felling and cross-cutting per $1,000 \mathrm{~m}^{3}$ of harvested volume in Sweden. In experiments, Dauda et al. (2015) showed that cutting speed in a fibre crop significantly affected cutting torque and cutting power requirements, with higher efficiency achieved at high cutting speeds as a result. However, in the present study, speed was excluded from the observations.

In the present study, brand new saw chains were used and replaced at approximately hourly intervals. In contractors' daily work, the changing of guide bars and chains does not happen at such short and regular intervals. When chains show some wear and become blunt over time, they are eventually replaced with new or sharpened ones. Nevertheless, there is variation between brand new chains and re-sharpened chains, as the study of Jönsson et al. (2016) showed. It revealed an approximately $9 \%$ shorter cutting time and $10 \%$ lower energy consumption when re-sharpened chains were used under the study's testing conditions.

The presented functions aptly describe the analysed data in this study. Data cleaning was necessary to extract extreme error values of stem diameters and cutting durations as well as multiple saw bar movements during cutting, which would have had an effect on the reliability of data analysis and the comparisons of cutting types (i.e. felling cutting vs. crosscutting). Whilst an exponential curve for the cutting duration as a function of the stem diameter was selected for felling cutting, a cubic relationship best described the cutting duration, depending on the stem diameter during cross-cutting. The functions work well above stem diameters of approximately $50 \mathrm{~mm}$. Values below this are basically unrealistic in final felling operations. For larger diameters, the study data was limited, and further studies will be required to confirm the precise trends of the presented functions. The automatic data recording method with short recording intervals proved satisfactory for the collection of the detailed information on the felling cutting and cross-cutting performance as a function of stem size. Detailed knowledge of the performance of the guide bar and chain activities might help the future development of intelligent machinery. Currently, operators visually detect the performance of the guide bar and chains, and they react when the chain is blunt. In future, detailed knowledge of the time or fuel consumption of such machine activity might eventually directly cause an automated reaction by the machine, e.g. by adjusting specific guide bar parameters (such as speed or pressure) or by informing the operator of the need to change the sawing chain. The efficiency of the entire operation may thus increase. However, this will need to be investigated by future research.

Acknowledgements The authors gratefully acknowledge Simo Tauriainen (Ponsse Oyj) and the contractors involved (Motoajo and Toropainen), as well as their harvester operators. The authors also wish to acknowledge AAC Global Oy for its language review and the valuable feedback and suggestions received from two anonymous reviewers.

Funding Open access funding provided by Natural Resources Institute Finland (Luke). This work was supported by the Bio Based Industries Joint Undertaking under the European Union's Horizon 2020 research and innovation programme, TECH4EFFECT-Techniques and Technologies for Effective Wood Procurement project [Grant Number 720757].

\section{Compliance with ethical standards}

Conflict of interest The author declare that they have no conflict of interest.

Open Access This article is licensed under a Creative Commons Attribution 4.0 International License, which permits use, sharing, adaptation, distribution and reproduction in any medium or format, as long as you give appropriate credit to the original author(s) and the source, provide a link to the Creative Commons licence, and indicate if changes were made. The images or other third party material in this article are included in the article's Creative Commons licence, unless indicated otherwise in a credit line to the material. If material is not included in the article's Creative Commons licence and your intended use is not permitted by statutory regulation or exceeds the permitted use, you will need to obtain permission directly from the copyright holder. To view a copy of this licence, visit http://creativecommons.org/licenses/by/4.0/. 


\section{References}

Alam M, Walsh D, Strandgard M, Brown M (2014) A log-by-log productivity analysis of two valmet 475EX harvesters. Int J For Eng 25(1):14-22

Arlinger J, Möller JJ (2014) Time studies based on automatic data collection. In: Proceedings of the 47th international symposium on forestry mechanisation: "forest engineering: propelling the forest value chain", Gerardmer, p 8, September 23-26 2014

Athanassiadis D, Lidestav G, Wasterlund I (1999) Fuel, hydraulic oil and lubricant consumption in swedish mechanized harvesting operations. J For Eng 10(1):59-66

Brown M, Ghaffariyan MR, Berry M, Acuna M, Strandgard M, Mitchell R (2020) The progression of forest operations technology and innovation. Aust For. https://doi.org/10.1080/00049 158.2020.1723044

Câmpu VR, Ciubotaru A (2017) Time consumption and productivity in manual tree felling with a chainsaw: a case study of resinous stands from mountainous areas. Silva Fenn. https://doi. org/10.14214/sf.1657

Ciubotaru A, Câmpu RV (2018) Delimbing and cross-cutting of coniferous trees-time consumption, work productivity and performance. Forests 9(4):206. https://doi.org/10.3390/f9040206

Dauda SM, Ahmad D, Khalina A, Jamarei O (2015) Effect of cutting speed on cutting torque and cutting power of varying Kenaf-stem diameters at different moisture contents. Pertanika J Trop Agric Sci 38(4):549-561

Haavikko H, Kärhä K, Hourula M, Palander T (2019) Attitudes of small and medium-sized enterprises towards energy efficiency in wood procurement: a case study of stora enso in Finland. Croat $\mathrm{J}$ For Eng 40(1):107-123

Harstela P (1991) Work studies in forestry. Silva Carelica 18, p 41

Holzleitner F, Stampfer K, Visser R (2011) Utilization rates and cost factors in timber harvesting based on long-term machine data. Croat J For Eng 32(2):501-508

Inberg J, Mattila J, Virvalo T (2002) Harvester boom tip acceleration control during a crosscutting: theoretical background. Int J For Eng 13(1):41-49

Jönsson P, Andersson M, Hannrup B, Henriksen F, Högdahl A (2016) Avverkningskapacitet för sågkedjor: en jämförande studie (Cutting capacity of saw chains: a comparative study). Arbetsrapport Från Skogforsk nr. 913-2016, p 46 (in Swedish with English summary)

Kärhä K, Kääriäinen H, Roininen K, Haavikko H, Palander T (2020) Koneittain isoa vaihtelua polttoaineen kulutuksissa. Energiatehokkuus puunhankinnassa: fuel consumption of harvesters and forwarders in forest work: a large follow-up study in Finland. Koneyrittäjä 1/2020: 24-25 (In Finnish)

Kärhä K, Räsänen M, Palander T (2019) The profitability of crosscutting practices in butt-rotten Picea abies final-felling stands. Forests 10(874):25p

Klvac R, Skoupy A (2009) Characteristic fuel consumption and exhaust emissions in fully mechanized logging operations. J For Res 14(6):328-334

Labelle ER, Bergen M, Windisch J (2017) The effect of quality bucking and automatic bucking on harvesting productivity and product recovery in a pine-dominated stand. Eur J For Res 136:639-652

Laitila J, Asikainen A, Nuutinen Y (2007) Forwarding of whole trees after manual and mechanized felling bunching in pre-commercial thinnings. Int J For Eng 18(2):29-39. https://doi. org/10.1080/14942119.2007.10702548

Lijewski P, Merkisz J, Fuć P, Ziółkowski A, Rymaniak L, Kusiak W (2017) Fuel consumption and exhaust emissions in the process of mechanized timber extraction and transport. Eur J For Res 136:153-160

Lindblad J, Kilpeläinen H, Heikkinen J (2018) Hakkuukonemittauksen tyvifunktio männyn tyviosan tilavuuden määrityksessä. Metsätieteen aikakauskirja 2018. Tutkimusartikkeli. p 26 (In Finnish). https://doi.org/10.14214/ma.7805

Lu K, Bi H, Watt D, Strandgard M, Li Y (2017) Reconstructing the size of individual trees using log data from cut-to-length harvesters in Pinus radiata plantations: a case study in NSW. Aust J For Res 29(1):13-33

Magagnotti N, Pari L, Spinelli R (2017) Use, utilization, productivity and fuel consumption of purpose-built and excavator-based harvesters and processors in Italy. Forests 8:485. https://doi. org/10.3390/f8120485

Manner J, Nordfjell T, Lindroos O (2013) Effects of the number of assortments and log concentration on time consumption for forwarding. Silve Fenn 47(4):19

Marenče J, Mihelič M, Poje A (2017) Influence of chain filing, tree species and chain type on cross cutting efficiency and health risk. Forests 8(12):464. https://doi.org/10.3390/f8120464

Melander L, Einola K, Ritala R (2019) Fusion of open forest data and machine fieldbus data for performance analysis of forest machines. Eur J For Res. https://doi.org/10.1007/s10342-019-01237-8

Melander L, Ritala R (2020) Separating the impact of work environment and machine operation on harvester performance. Eur J Forest Res. https://doi.org/10.1007/s10342-020-01304-5

Möller JJ, Arlinger J, Hannrup B, Jönsson P (2008) Virkesvärdestest 2006. Timber value trials 2006. Redogörelse Nr 5, 2008. p 68 (in Swedish with English summary)

Nurminen T, Korpunen H, Uusitalo J (2006) Time consumption analysis of the mechanized cut-to-length harvesting system. Silva Fenn 40(2):335-363

Nuutinen Y, Väätäinen K, Asikainen A, Prinz R, Heinonen J (2010) Operational efficiency and damage to sawlogs by feed rollers of the harvester head. Silva Fenn 44(1):121-139

Prinz R, Spinelli R, Magagnotti N, Routa J, Asikainen A (2018) Modifying the settings of CTL timber harvesting machines to reduce fuel consumption and $\mathrm{CO}_{2}$ emissions. J Clean Prod 197:208-217

Suvinen A, Saarilahti M (2006) Measuring the mobility parameters of forwarders using GPS and CAN bus techniques. J Terramechanics 43:237-252

Väätäinen K, Ovaskainen H, Ranta P, Ala-Fossi A (2005) Hakkuukoneenkuljettajan hiljaisen tiedon merkitys hakkuutulokseen työpistetasolla (The significance of harvester operator's tacit knowledge on cutting with single-grip harvester). Finnish forest research institute. Research Notes 937. p 100 (In Finnish)

Väätäinen K, Asikainen A, Sikanen L, Ala-Fossi A (2006) The cost effect of forest machine relocations on logging costs in Finland. For Stud/Metsanduslikud Uurimused 45:135-141

Publisher's Note Springer Nature remains neutral with regard to jurisdictional claims in published maps and institutional affiliations. 